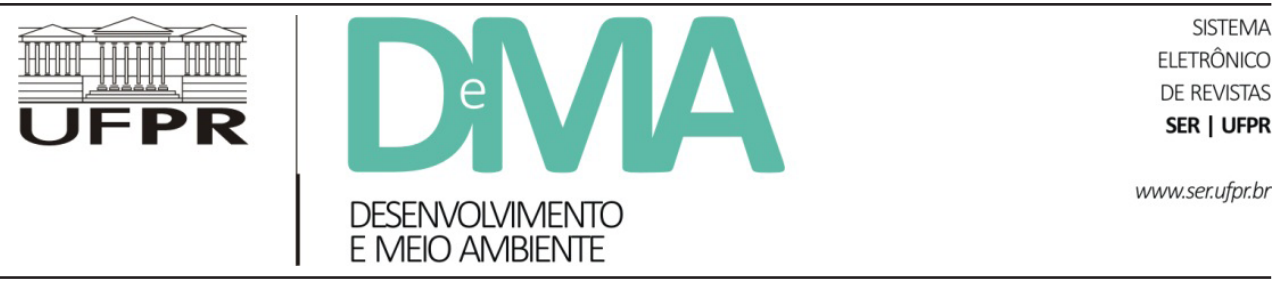

\title{
Fenômenos sociais e problemáticas em águas amazônicas: sentidos, percepções e representações sociais
}

\author{
Phenomena and Social Issues in Waters Amazon: \\ Senses, Perceptions, and Social Representations
}

\author{
Klondy Lúcia de Oliveira AGRA ${ }^{1^{*}}$ \\ ${ }^{1}$ Faculdade Interamericana de Porto Velho, Porto Velho, RO, Brasil. \\ *E-mail de contato: klondy2@gmail.com
}

Artigo recebido em 31 de janeiro de 2016, versão final aceita em 20 de julho de 2016.

RESUMO: Com o objetivo principal de conhecer como se constituem os sentidos em comunidades amazônicas, as percepções dos sujeitos e suas representações sociais sobre a importância, o uso e a preservação da água para, assim também, conhecer as lógicas dessas comunidades, fenômenos sociais e problemáticas que as circundam, fez-se uma pesquisa qualitativa, sob o quadro teórico da abordagem da Geografia Cultural, em sua vertente fenomenológica, cuja interface permeou a Geografia Sociocultural. O recorte espacial deste estudo são 06 (seis) comunidades inseridas em duas cidades do Estado de Rondônia: Porto Velho e Guajará-Mirim. Todas as comunidades objeto da pesquisa apresentam paisagens culturais que, embora existam em constante fluxo de troca de saberes com o urbano, insistem e permanecem na experiência de vida com sentidos e significados construídos, especializados ou reavaliados à margem dos rios. Para atingir o objetivo proposto, utilizaram-se para a coleta de dados os seguintes instrumentos: a entrevista não estruturada e os mapas mentais. Na condução das entrevistas e na análise das narrativas, utilizou-se o método da Grounded Theory, com auxílio do ATLAS/ ti. Na análise dos mapas mentais, empregou-se a metodologia Kozel. Na totalidade deste estudo, com o auxílio dessa Geografia humanizada, notou-se que as comunidades amazônicas observadas expuseram sentidos íntimos em relação às águas que constituem suas identidades e, a partir desses sentidos, identificaram as conexões entre os fenômenos sociais e as problemáticas que cercam a sua água, o seu mundo vivido. Tais conexões as conduzem às lógicas de temor e preocupação em relação à água que constitui o seu lugar. Observou-se, também, que são essas lógicas de comunidade que lhes possibilitam a união, o enfrentamento e a busca permanente por soluções.

Palavras-chave: sentido; água; Amazônia; lógica de comunidade.

ABSTRACT: In this study, with the main objective of observing how the senses in Amazonian communities are constituted, the perception of the subjects and their social representations about the importance, the use and preservation of water for, then, understand the logic of these communities, social phenomena and problems surrounding them, I made a qualitative research, under the theoretical framework of the Cultural Geography approach in its 
slope phenomenological, with Sociocultural Geography interface. The spatial areas of this study are six (06) communities inserted in two cities of the State of Rondônia: Porto Velho and Guajará-Mirim. All communities, researched, have cultural landscapes that while are in constant flow of knowledge exchange with the urban insist to and remain on the life experience with built senses and meanings, skilled or reassessed on the river banks. To reach that goal I used the following instruments for data collection: the unstructured interview and mental maps. In conducting the interviews and analysis of the narratives, I worked the method of Grounded Theory, using the software ATLAS /it. In the analysis of mental maps, I used Kozel's methodology. In all of this study, with the help of this humanized Geography, I could note that the observed Amazonian communities exposed intimate senses in relation to waters that constitute their identities and, through these senses, identified the connections between social phenomena and problems surrounding their water, their place. Such connections lead their senses to the logic of fear and concern about the water that constitutes their place. These community logics were noticed to enable them to unity, confrontation and the ongoing search for solutions.

Keywords: sense; water; Amazon; logic of the community.

\section{Introdução}

A Amazônia é a região que comporta a maior e mais extensa bacia hidrográfica continental de drenagem superficial do planeta, ocupando uma área total de $7.008 .370 \mathrm{~km}^{2}$, desde as nascentes, nos Andes Peruanos, até sua foz no oceano Atlântico (PNRH, 2010). Sua extensão no território brasileiro representa $61 \%$ de todo o território nacional, ou seja, mais de 05 (cinco) milhões de quilômetros quadrados, abrangendo 10 estados (Acre, Amapá, Amazonas, parte do Mato Grosso, Pará, Rondônia, Roraima, Tocantins, parte do Maranhão e parte de Goiás). Uma extensa e rica região, com comunidades diversas que passam por transformações ocorridas pelo desmatamento acelerado de suas áreas, pela implantação de projetos públicos e privados e pela contaminação de suas águas (Dias \& Aragón, 1987; Aragón, 2006).

Pela intensa transformação cultural que tais mudanças provocam nessas comunidades, com a construção de novos sentidos e a alteração de suas paisagens naturais e culturais, e pela importância da água, não só para essas comunidades, mas para toda a humanidade, justifica-se esta pesquisa.
Com o objetivo principal de conhecer como se constituem os sentidos culturalmente construídos em comunidades amazônicas, as percepções dos sujeitos e suas representações sociais sobre a importância, o uso e a preservação da água para, assim também, conhecer as lógicas dessas comunidades, fenômenos sociais e problemáticas que as circundam, fez-se este estudo com a certeza de que a paisagem cultural encontrada em cada uma das comunidades responde a sentidos, percepções e representações sociais próprias, isto é, são apenas pequeninas e importantes peças que integram a imensa e diversa paisagem cultural amazônica.

Privilegiou-se, aqui, a paisagem geográfica impregnada de sentidos e valores, passível de observação, descrita e representada por linguagens explicitadas em ícones diversificados. Entendendo a paisagem como a expressão captada desses elementos. Uma imagem que permite realizar a interação entre os sentidos e a interpretação do observador, buscando entender, criticar e recriar aquilo que se observa. "A paisagem é um conjunto, uma convergência, um momento vivido. Uma ligação interna, uma impressão, que une todos os elementos" (Dardel, 2011, p. 30). 
Ademais, as paisagens, neste estudo, foram tomadas a partir das vidas cotidianas e estão cheias de sentidos culturais e significados. Com os dados proporcionados pela pesquisa de campo, procurou-se decodificar essas paisagens, porque a geografia está em toda parte, reproduzida diariamente pelo sujeito integrante dessa paisagem cultural. A recuperação desses sentidos e significados em paisagens comuns diz muito sobre esses sujeitos culturais e pode proporcionar uma geografia efetivamente humana e relevante, que pode contribuir para o próprio núcleo de uma educação humanista: melhor conhecimento e compreensão de nós mesmos, dos outros e do mundo que compartilhamos (Cosgrove, 1999).

Como espaço amazônico, no contexto deste estudo, escolheram-se seis (06) comunidades amazônicas inseridas em duas cidades distintas: na cidade de Porto Velho, capital do Estado de Rondônia, e em Guajará-Mirim, a segunda cidade fundada nesse Estado. Um Estado que, por sua diversidade, seus problemas socioculturais e seu rápido crescimento demográfico, é um retrato síntese da região amazônica.

O ser humano amazônico observado neste estudo é aquele que, embora esteja a poucos minutos do centro das cidades investigadas, optou por viver às margens de rios. Comunidades que fazem parte de uma paisagem observada e admirada por muitos, mas transformada e vivida por esse ser humano. Um ser que dá uma caracterização diferente ao seu mundo, uma concepção de natureza que integra o urbano e o rural em seu modo de vida com dois elementos essenciais à sua paisagem: as águas e as matas. Importante ressaltar que, ao procurar pelo sentido do ser humano amazônico, compreendeu-se que esse homem/mulher não é somente o nato do lugar, mas também aquele ser humano que escolheu viver e sonhar na paisagem natural, modificando-a e construindo a paisagem cultural observada, um ser que se apropriou do espaço como o seu lugar.

\section{A compreensão do sentido}

Graças à pluralidade e ao dinamismo da Geografia Cultural, os estudos geográficos se voltam ao sentido, ao significado, às percepções, perpassando cognições, visando às representações de paisagens, espaços e lugares valorizados individualmente ou intersubjetivamente.

No entanto, com essa busca do sentido humano pela Geografia, uma inquietação tornou-se frequente na compreensão de culturas diversas: o que está sendo observado em particulares culturas, os sentidos ou os significados? Os significados culturais e os sentidos dizem respeito ao mesmo objeto? Quem pode desvelar as velas ${ }^{1}$, fornecer itinerários e rumos corretos ao geógrafo na análise de paisagens culturais diferençadas: o sentido ou o significado?

Com o ser humano tomado como seu centro de interesse, a Geografia sente necessidade de (re) conhecer o seu mundo circundante, seus valores, seus marcadores, seus sentidos concretos. Assim, os estudos geográficos passam a integrar outros aportes na interface com os signos linguísticos de Ferdinand Saussure (1857-1913), a pragmática de Charles Sanders Peirce (1839-1914) ou reflexões teórico-filosóficas pelos estudos de Bourdieu (19302002), Heidegger (1889-1976), Husserl (19591938), entre outros.

Heidrich (2013), em seu artigo "Território e cultura: argumento para uma produção de sentido",

\footnotetext{
1 Desvelar as velas é um termo usado por Dardel (2011) para referir-se a descobrir o que está oculto na análise geográfica para a compreensão.
} 
apresenta a definição de sentido com base nos estudos sociológicos de Berger \& Luckmann (2012, p. 15): "Sentido é a consciência de que existe uma relação entre as experiências". A partir dessa compreensão, Heidrich complementa: "Qualquer objeto ou ação para os quais movimentamos nosso olhar aparece com importância e validade por causa do sentido humano que possui. Todo o mundo geográfico é impregnado de sentidos, tudo tem uma função e um significado" (Heidrich et al., 2013, p.53).

Estudos com aportes fenomenológicos como os de Tuan e Buttimer, assim como estudos advindos de outras bases teóricas, quando abordam a constituição do sentido, convergem a um só ponto: a cultura. Ou seja, o sentido é constituído culturalmente e, por isso, é um processo que está presente em todos os universos culturais.

Com base nos estudos da abordagem fenomenológica, a partir de filosofias de sentido, Fernandes \& Gil Filho (2011), em seu artigo "Geografia em Cassirer: perspectivas para a Geografia da Religião", afirmam que tais estudos só vêm enriquecer a pluralidade de interpretações sobre o espaço. De acordo com esses autores, a virada linguística nas ciências sociais abre "[...] uma riqueza de possibilidades ao enfatizar as representações", e complementam: "[...] nesse contexto a Geografia tem se dedicado a compreender o sentido dos espaços sígnicos" (Fernandes \& Gil Filho, 2011).

Para este estudo, que visa conhecer os sentidos dos homens/mulheres amazônicos, buscou-se pela compreensão desse sentido presente no olhar geográfico e de como esse sentido culturalmente construído conduz a diferentes percepções, visões de mundo e construções de pontos de vista, em Frege (1978) e a sua concepção de unidade de sentido, com base no clássico ensaio "Sobre o sentido e a referência". A escolha da unidade de sentido, exposta por Frege (1978) em seu ensaio "Sobre o sentido e a referência", na elaboração deste estudo, reside no fato de que, embora teóricos da Geografia falem sobre o sentido e o definam como um fato/ fenômeno cultural, observou-se a ausência de uma explicação de como se constitui essa unidade de sentido que acompanha o viver do ser humano ${ }^{3}$.

Frege não produziu extenso material a ser observado, justamente por centrar seu interesse na lógica matemática e não na filosofia da linguagem. No entanto, no texto aqui utilizado, o autor desenvolve instigantes tópicos relativos a conhecimento, verdade, existência, sentido, significado e linguagem. Essas suas investigações, com base na lógica, trouxeram à semântica orientações de forma decisiva à construção de uma teoria compreensiva da construção do sentido (Frege, 1978).

Gottlob Frege utiliza uma grande quantidade de argumentos para sustentar logicamente a afirmação de que o significado não é o objeto a que uma palavra se refere e que é necessário diferenciar, ainda, o objeto real e a palavra daquilo que é compartilhado socialmente como sendo o significado desse sinal e daquilo que cada um entende particularmente como sendo sua significação, conforme se demonstra na Figura 1:

\footnotetext{
2 Esse ensaio foi escrito com problemas da lógica em mente (isto é, a relação de "igualdade") e é uma amostra dos primeiros exemplos de análise filosófica a apontar que o problema do sentido invade a língua natural e que não é um problema restrito à matemática ou à lógica formal. Deste ponto de vista, Frege, como C. S. Pierce, antecipa a preocupação de filósofos e críticos com os problemas que envolvem a língua e o significado, particularmente quando problemas semânticos e epistemológicos se sobrepõem, mas exigem diferenciação. Cf. In: Adams and Searle, 1985, p. 624. ${ }^{3}$ A unidade de sentido exposta em Frege (1978) tem acompanhado as pesquisas da autora deste artigo, em trabalhos que analisam como autores
estrangeiros traduzem a cultura amazônica às suas audiências.
} 


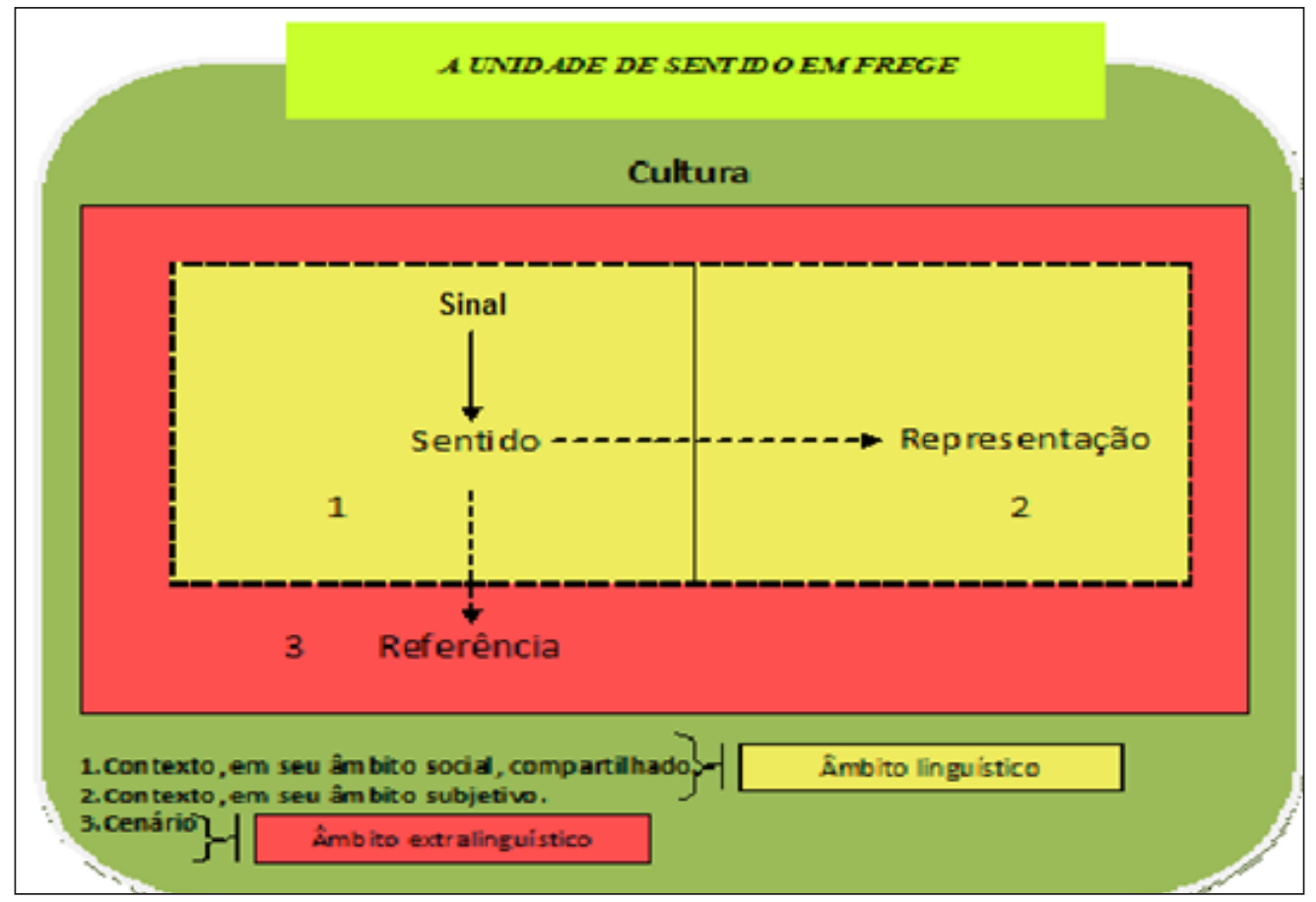

FIGURA 1 - A compreensão do sentido culturalmente construído em Frege (1978).

FONTE: Frege, G. Lógica e filosofia da linguagem. São Paulo: Cultrix (1978). Organizado por Ferrarezi Jr. (2003).

Adaptado por Agra, Klondy (2013).

Compreende-se, desse modo, que a conexão regular entre o sinal ${ }^{4}$ (signo ou símbolo), seu sentido e sua referência é de tal modo que ao sinal corresponde um sentido determinado e ao sentido, por sua vez, corresponde uma referência determinada, enquanto que a uma referência (a um objeto) não deve pertencer apenas um único sinal. Porém, nem sempre ao sentido corresponde uma referência: "entender-se um sentido nunca assegura sua referência" (Frege, 1978, p. 63). Tomem-se, por exemplo, expressões como a Boiúna ${ }^{5}$, fada, algum assistente, qualquer passageiro do avião, etc.; apesar de podermos apreender o sentido de tais expressões, elas não nos garantem uma referência.

Além desses componentes do sinal - o sentido e a referência - Frege (1978) introduz outro componente: a representação associada ao sinal. Diferente do sentido do sinal, que seria uma imagem apreendida coletivamente, portanto, de modo mais objetivo, a representação em Frege é inteiramente

4 Utiliza-se a palavra sinal neste estudo e não signo, para diferenciar do signo linguístico descrito pelo linguista Ferdinand Saussure (18571913). Sinal é utilizado como sinônimo de signo ou símbolo.

5 A Boiúna, ou cobra-grande, é um mito amazônico de origem ameríndia, descrito como uma enorme cobra escura capaz de virar as embarcações. Também pode imitar as formas das embarcações, atraindo náufragos para o fundo do rio (Dicionário Houaiss da Língua Portuguesa. Rio de Janeiro: Objetiva, 2001). 
subjetiva. A referência e o sentido de um sinal para Frege devem ser distinguidos da representação associada a esse sinal.

Frege ainda introduz o mundo real em suas considerações e explicita que o sinal (signo ou símbolo) designa uma referência (a coisa do mundo real que é designada). Mas a conexão entre o sinal e a coisa designada é arbitrária: "ninguém pode ser impedido de empregar qualquer evento ou objeto arbitrariamente produzidos como um sinal para qualquer coisa" (Frege, 1978, p. 62-63). O que é arbitrária é a conexão entre o sinal e a referência; essa conexão, para Frege, pode ser alterada, ou deformada, pelo falante. Então, o sinal é o elemento que remete à significação. $\mathrm{O}$ sinal é mais do que a palavra, mas é inclusive a palavra. A referência é a substância - quando ela existe. O sentido é a ideia compartilhada como referente, isto é, uma concepção geral que permite o entendimento dos significados simbólicos entre os membros de uma mesma cultura (Frege, 1978).

Desse modo, reconhece-se um diálogo entre o sentido exposto por Berger \& Luckmann (2012) e comentado por Heidrich (2013) com a unidade de sentido exposta por Frege (1978), pois, se é o sentido a consciência de que existe relação entre as experiências, é esse mesmo sentido que permite o entendimento e a compreensão entre os membros de uma mesma cultura.

Ademais, os sentidos humanos, embora façam parte da consistência humana, são sempre influenciados pelo contexto e cenário, ou seja, por serem construídos culturalmente, é por meio desses sentidos que os seres humanos se relacionam com o meio. Assim, cada homem/mulher, a partir de sua cultura, do seu mundo vivido, percebe o mundo exterior de formas distintas.

Por ser esse sentido culturalmente construído o condutor às percepções de formas distintas, é ele também quem conduz ao compreender ou não compreender, ao gostar ou ao não gostar. Fatores que conduzem as pessoas a verem somente o que interessa ou ao ouvir o que atende seus próprios interesses. A cultura influencia fortemente a percepção do indivíduo, sua maneira de ver e sua maneira de pensar (Tuan, 2012). Portanto, o sentido culturalmente construído interfere também na valorização ou não dos elementos naturais.

$\mathrm{O}$ homem/mulher vive a remoldar de sentidos e significações o mundo. Graças às situações e tensões culturais a que está vinculado, esse ser cultural cria, renova, interfere, dá sentido à sua existência. Por isso mesmo esse ser cultural vê, sente, compreende e divulga suas crenças e pensamentos com sentidos culturalmente construídos (Claval, 2010).

O sentido construído culturalmente é o responsável pelos símbolos linguísticos utilizados na comunicação de atores de uma mesma comunidade, porque esse sentido é compartilhado pelos falantes de uma língua. Definido como uma ideia geral que os falantes de uma língua associam a um sinal qualquer a respeito de um objeto do mundo real ou de mundos possíveis, o sentido é o responsável pela possibilidade de comunicação entre usuários de uma língua. Assim, quando um locutor fala uma palavra qualquer ou utiliza-se de um gesto culturalmente definido, espera-se que seu interlocutor entenda o que está falando.

As diferentes comunidades amazônicas variam no estilo de construção, em sua operação e manutenção, nas entidades que as preenchem e as decoram. Seus códigos culturais são sistemas pelos quais os seus mundos são definidos, descritos e entendidos. Os sentidos que levam ao significado revelado por uma cultura são construídos socialmente.

Portanto, a partir da unidade de sentido exposta em Frege (1978), compreende-se que, nos estudos geográficos, o que deve ser observado 
em particulares culturas são os sentidos, pois são eles que conduzem aos significados culturais. É a partir desse sentido construído culturalmente que o geógrafo pode desvelar os significados, obter itinerários e rumos corretos à análise de paisagens culturais diferençadas.

\section{Um olhar revelador sobre as narrativas com auxílio do software ATLAS/ti}

Paul Claval (2004), em seu artigo "Do olhar do geógrafo a Geografia como estudo do olhar dos outros", afirma que "a prática geográfica nunca foi tão simples como a análise do olhar do geógrafo poderia o deixar crer". Na concordância com esse pensamento, procurou-se por novas metodologias que fornecessem a este estudo uma análise que desvendasse o que o olhar geográfico buscava esclarecer e optou-se pelas entrevistas não estruturadas e pelo método da Grounded Theory na condução do mesmo.

Na busca da leitura e da compreensão do outro, sua interpretação da realidade e por informações novas, obteve-se a narrativa dos colaboradores coautores e, após o tratamento de cada uma dessas narrativas orais, fez-se uma leitura exploratória em busca da essência do ser humano amazônico e sua relação com a água.

Para tanto, após a leitura exploratória das entrevistas, com o objetivo de identificar os conceitos-chave da pesquisa (Tabela 1), atentou-se para:

- o papel da água na configuração dos sujeitos e no tecido social das comunidades;

- conexões entre os fenômenos sociais e as problemáticas que cercam a água;

- noção de preservação - das comunidades sobre o uso da água.
TABELA 1 - Identificação dos conceitos-chave da pesquisa.

\begin{tabular}{|c|c|c|}
\hline Papel da água & $\begin{array}{l}\text { Ligação fenomênos } \\
\text { sociais e água }\end{array}$ & $\begin{array}{c}\text { Noção de } \\
\text { preservação }\end{array}$ \\
\hline $\begin{array}{l}\text { Qual o espaço } \\
\text { privilegiado } \\
\text { da água na } \\
\text { vida dessas } \\
\text { comunidades? }\end{array}$ & $\begin{array}{l}\text { Que características } \\
\text { envolvem, em } \\
\text { geral, as lógicas } \\
\text { das comunidades } \\
\text { Amazônicas no que diz } \\
\text { respeito aos fenômenos } \\
\text { sociais e problemáticas } \\
\text { em suas águas? }\end{array}$ & $\begin{array}{c}\text { Quais os fatores } \\
\text { que incidem no } \\
\text { pensamento das } \\
\text { comunidades } \\
\text { investigadas sobre o } \\
\text { uso e a preservação } \\
\text { da água? }\end{array}$ \\
\hline $\begin{array}{c}\text { Que papel } \\
\text { cumpre a água na } \\
\text { configuração dos } \\
\text { sujeitos e no tecido } \\
\text { social dessas } \\
\text { comunidades? }\end{array}$ & & $\begin{array}{l}\text { Quais as conexões } \\
\text { entre os sentidos, } \\
\text { as percepções e } \\
\text { as representações } \\
\text { sociais das } \\
\text { comunidades } \\
\text { Amazônicas quanto } \\
\text { aos cuidados com a } \\
\text { água? }\end{array}$ \\
\hline
\end{tabular}

FONTE: A autora.

Essa fase consistiu em uma exploração inicial do material por meio da leitura, a fim de melhor compreendê-lo e, desse modo, iniciar a identificação das unidades básicas de análise, ou seja, conceitos indicadores de sentidos culturalmente construídos que fornecessem caminhos ao desenvolvimento de categorias a serem dispostas no software ATLAS/ti.

Após essa pré-análise, criou-se a unidade hermenêutica no software ATLAS/ti, que permitiu a descoberta de fenômenos complexos, os quais, possivelmente, não seriam detectáveis na simples leitura do texto, principalmente em relação à técnica tradicional de tratamento dos dados manualmente, com a utilização de lápis, tesoura e cola. Isso porque, com o auxílio da tecnologia, foi possível integrar as unidades hermenêuticas (projetos primários) entre si.

Para esse fim, os arquivos textuais (as narrativas obtidas com as entrevistas realizadas nas comunidades investigadas) foram inseridos no programa. 
Feita essa inserção, cada entrevista passou a ser um documento primário (primary document). Os documentos primários foram organizados de acordo com cada comunidade de interesse para que, posteriormente, fosse possível a comparação. Portanto, os documentos foram divididos em famílias - cinco comunidades inseridas em Porto Velho (vinte e cinco entrevistas) e uma comunidade inserida em Guajará-Mirim (seis entrevistas).

Após a organização dos documentos na unidade hermenêutica, a próxima etapa foi codificá-los, isto é, classificar o texto de acordo com categorias e recortar o texto em códigos. A aplicação dos códigos foi direcionada tendo em vista os objetivos da pesquisa, a interpretação e a sumarização dos dados ${ }^{6}$.

A codificação iniciou-se com a leitura do texto em busca de informações salientes (citações), observando-se o que foi proposto na pré-análise, e a aplicação de códigos ao texto, ou seja, a rotulação das instâncias relevantes de cada documento (desenvolvimento de categorias). À aplicação dos códigos soma-se a comparação constante dos trechos codificados com o mesmo código. Por conseguinte, os códigos criados foram sendo aplicados a novas instâncias, tendo em vista a busca por padrões e variações nas narrativas dos informantes que trouxessem à tona os seus sentidos culturalmente construídos.

Posteriormente à aplicação inicial dos códigos aos documentos, buscou-se refinar a codificação, criando ou excluindo códigos, visando à saturação da codificação, ou seja, uma classificação das citações do texto que atendesse ao máximo os objetivos de pesquisa, extraindo todas as informações possíveis? Realizado o refinamento da codificação, os códigos criados foram agrupados em famílias, o que significa o agrupamento de códigos que direcionam para o entendimento de uma mesma questão. Feito isso, houve a categorização dos documentos primários.

Após a categorização de todas as entrevistas (documentos primários), geraram-se outputs dos códigos e das citações. Outputs são relatórios gerados automaticamente pelo ATLAS/ti, sempre relevantes, pois fornecem à pesquisa uma ideia geral da categorização que foi realizada, permitindo que exista a leitura de todas as citações organizadas por código. Tais relatórios compuseram a maior parte da análise qualitativa dos documentos, de modo que são úteis para a interpretação dos dados e para a formulação de inferências de pesquisa.

O ATLAS/ti permitiu ainda o tratamento estatístico aos códigos inseridos nos documentos. Uma das opções de output no menu de códigos é a geração de matrizes no Excel, nas quais estão dispostos todos os documentos primários e a contagem dos códigos (por documento) inseridos. A partir dessa ferramenta, foi possível ter um levantamento quantitativo dos códigos por meio da elaboração de gráficos, o que também contribui para a formulação de inferências e, principalmente, para a análise comparativa entre os sentidos e percepções fornecidos pelos colaboradores das várias comunidades de Porto Velho e da comunidade de Guajará-Mirim.

A seguir, fez-se uso da ferramenta do ATLAS/ ti chamada Query Tool. Essa ferramenta forneceu

\footnotetext{
${ }^{6}$ Os principais elementos interligados ao software ATLAS/ti e que estão dentro de um projeto, denominado unidade hermenêutica, são: os documentos primários (P-Docs), as citações (Quotes), os códigos (Codes) e as notas (Memos). Esses elementos dão origem às teias (ferramentas de análise que podem ser utilizadas para ilustrar as relações que foram analisadas pela pesquisadora).

7 Nesse momento, embora não estivesse incluso nenhum objetivo específico ou perguntas de pesquisa sobre as hidrelétricas construídas no Rio Madeira, optou-se pela inclusão de códigos referentes a elas por se entender que as mesmas fazem parte de sentidos, percepções e representações sociais das comunidades analisadas e estão presentes em todas as narrativas.
} 
a busca textual à pesquisa. Diferente de uma busca de texto simples pela contagem de palavras, essa ferramenta permitiu que houvesse a procura das citações marcadas por esta pesquisadora em todos os documentos primários, bem como a identificação de relações entre os códigos (de famílias diferentes) e as citações. Após a análise em separado de cada comunidade, o ATLAS/ti forneceu à pesquisa as redes formadas com a totalidade dos dados obtidos nas comunidades de Porto Velho.

Ademais, após o fornecimento dos dados à pesquisa com a construção dessas redes gráficas, auxiliado pelo software ATLAS/ti, ainda se obteve para análise as tabelas de dados com as semelhanças e diferenças de sentidos, percepções e pontos de vista nas diferentes comunidades porto-velhenses, como se expõe abaixo (Tabela 2):

A seguir, expõem-se, na Tabela 3, os resultados obtidos na comparação entre a comunidade de Guajará-Mirim e as comunidades de Porto Velho: As diferenças e similaridades apontadas nas tabelas 2 e 3 foram acompanhadas das redes gráficas ${ }^{8}$.

A análise com o auxílio do ATLAS/ti privilegiou o contexto, os processos e a subjetividade em que estavam envolvidos esses colaboradores, portanto, ao se inserirem os dados, procurou-se pela correta compreensão dos sentidos e significados em cada enunciação.

TABELA 2 - Semelhanças e diferenças entre as comunidades de Porto Velho.

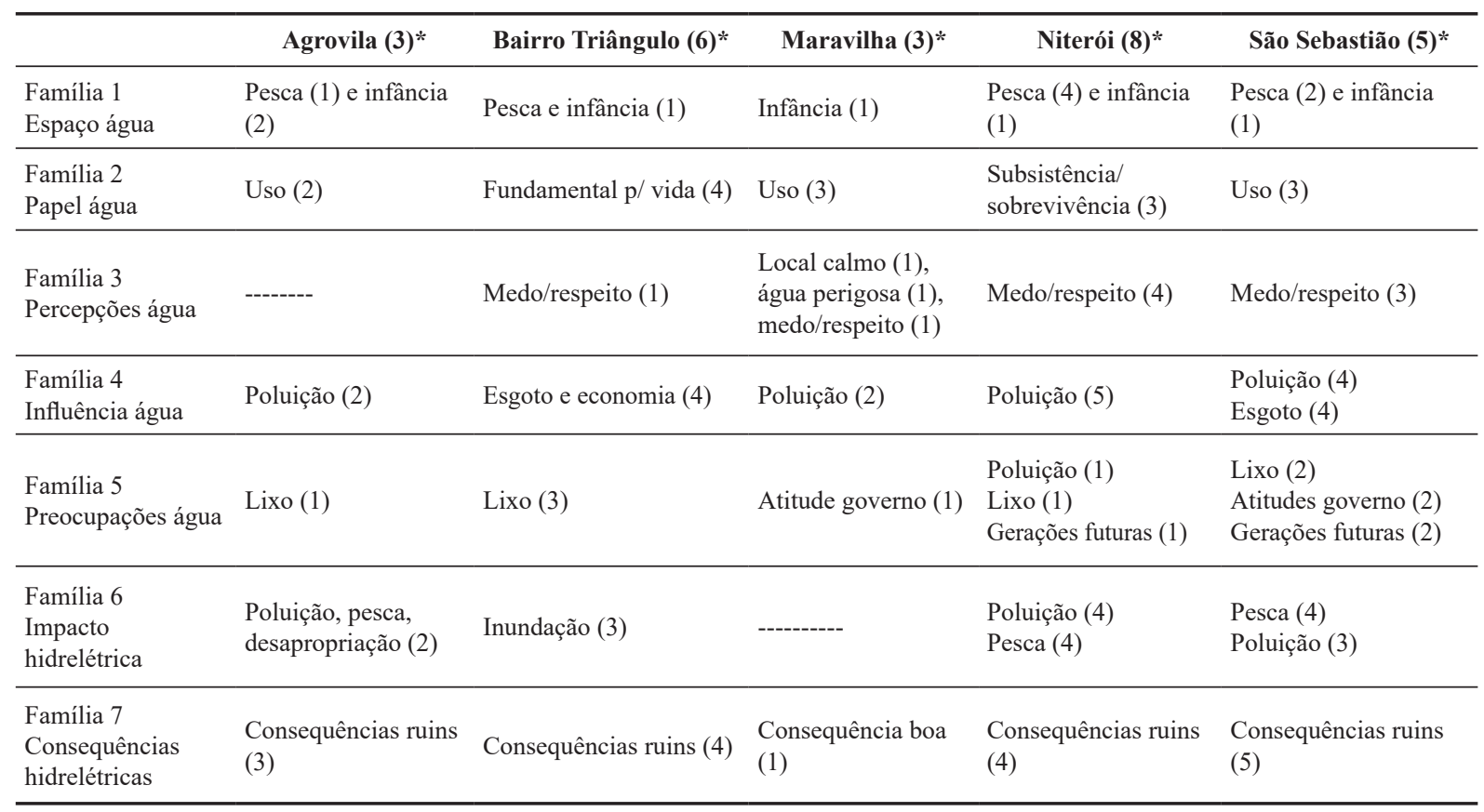

*Número de entrevistados.

8 Todo o material produzido com auxílio do ATLAS/ti está disponível no DVD, anexo à Tese Doutoral Águas da Amazônia: sentidos, percepções e representações no endereço: <http://dspace.c3sl.ufpr.br/dspace/handle/1884/37976>. 
TABELA 3 - Semelhanças e diferenças entre Guajará-Mirim e Porto Velho.

\begin{tabular}{|c|c|c|}
\hline & $\begin{array}{c}\text { Guajará-Mirim } \\
(6)^{*}\end{array}$ & Porto Velho (25)* \\
\hline $\begin{array}{l}\text { Família } 1 \\
\text { Espaço água }\end{array}$ & $\begin{array}{l}\text { Pesca (5) e } \\
\text { infância (4) }\end{array}$ & Pesca (8) e infância (6) \\
\hline $\begin{array}{l}\text { Família } 2 \\
\text { papel água }\end{array}$ & $\begin{array}{l}\text { Lazer/diversão (4) } \\
\text { Alimento (4) }\end{array}$ & $\begin{array}{l}\text { Uso/Subsistência/ } \\
\text { sobrevivência/ fund. à } \\
\text { vida (17) }\end{array}$ \\
\hline $\begin{array}{l}\text { Família } 3 \\
\text { Percepções água }\end{array}$ & $\begin{array}{l}\text { Segurança/local } \\
\text { calmo (3) }\end{array}$ & $\begin{array}{l}\text { Medo/respeito (9) } \\
\text { Perigosa (1) } \\
\text { Local calmo/tranquilo (1) }\end{array}$ \\
\hline $\begin{array}{l}\text { Família } 4 \\
\text { Influência água }\end{array}$ & $\begin{array}{l}\text { Desmatamento (3) } \\
\text { Poluição (3) } \\
\text { Esgoto (3) }\end{array}$ & $\begin{array}{l}\text { Esgoto (8) } \\
\text { Poluição (13) } \\
\text { Economia (4) }\end{array}$ \\
\hline $\begin{array}{l}\text { Família } 5 \\
\text { Preocupações } \\
\text { água }\end{array}$ & $\begin{array}{l}\text { Assoreamento (3) } \\
\text { Gerações } \\
\text { futuras (3) } \\
\text { Poluição (3) }\end{array}$ & $\begin{array}{l}\text { Lixo (7) } \\
\text { Gerações futuras (3) } \\
\text { Poluição (1) } \\
\text { Atitude do Governo (3) }\end{array}$ \\
\hline $\begin{array}{l}\text { Família } 6 \\
\text { Impactos } \\
\text { hidrelétrica }\end{array}$ & $\begin{array}{l}\text { Inundação (2) } \\
\text { Pesca (2) } \\
\text { Migração cidade (2) }\end{array}$ & $\begin{array}{l}\text { Poluição (9) } \\
\text { Pesca (10) } \\
\text { Inundação (3) }\end{array}$ \\
\hline $\begin{array}{l}\text { Família } 7 \\
\text { Consequências } \\
\text { hidrelétricas }\end{array}$ & $\begin{array}{l}\text { Consequências } \\
\text { ruins (3) }\end{array}$ & $\begin{array}{l}\text { Consequências ruins (16) } \\
\text { Consequências boas (1) }\end{array}$ \\
\hline
\end{tabular}

*Número de entrevistados

\section{Os mapas mentais e as paisagens: representações repletas de sentidos}

Com a crença de que os mapas como representações simbolizadas da realidade podem ser um ponto de partida para as pesquisas em geral, utilizou-se, neste estudo, os mapas mentais para conhecer acerca das percepções das comunidades pesquisadas sobre a água. Mapas mentais, aqui, são entendidos como representações que revelam a ideia que as pessoas têm do mundo e, assim, vão além da percepção individual, refletindo a construção social.

Com o reconhecimento de que cada colaborador é um sujeito atuante na paisagem que integra e vivifica intensamente, acredita-se que a percepção individual se dá pelos seus sentidos construídos culturalmente, ou seja, são esses sentidos que permitem perceber, por meio da captação dos estímulos externos representados por essa subjetividade, o que está a sua volta de maneira particular.

Com essa compreensão, em busca dos sentidos, percepções e representações sociais dos seres humanos inseridos nas comunidades de Porto Velho e de Guajará-Mirim, enfatiza-se, nesta pesquisa, o pensamento geográfico de que as representações são construções decorrentes da vivência cultural, da construção dos sentidos, dos significados e subjetividades espaciais. Refletindo, desse modo, a percepção e a compreensão sociocultural dos indivíduos que as produzem, perpassadas por diferentes prismas em direção ao representativo/simbólico que se situa na base da relação sujeito/signo/imagem (Kozel, 2007).

As paisagens culturais dessas comunidades amazônicas são, portanto, aqui consideradas por esse ângulo e compreendidas não apenas como uma soma de objetos, mas como uma forma de linguagem explicitada no sistema de relações sociais no qual estão inseridos sentidos, valores, atitudes e vivências.

A linguagem aparece como uma semantização que os sujeitos fazem de seu espaço vivido ou uma modalidade privilegiada de representação. Essa linguagem é referendada por signos que são construções sociais. De acordo com Kozel (2007), os mapas mentais são "[...] formas de linguagem que refletem o espaço vivido representado em todas as suas nuances, cujos signos são construções sociais". Um dialogismo em todas as suas nuances, cujos signos são construções sociais que podem ser construídas por intermédio de imagens, sons, formas, odores, sabores, porém seu caráter significativo prescinde de uma forma de linguagem para ser comunicado. Penetrar nessa intrincada rede 
de relações pressupõe construção e ação de uma consciência e isso requer diferentes linguagens.

$\mathrm{Na}$ compreensão desse homem/mulher encontrado no espaço amazônico, contexto da pesquisa, utilizou-se o mapa mental como um aporte que reflete uma forma de linguagem, a ser lido e compreendido, um recurso metodológico de apoio ao conhecimento dos sentidos que cada um dos colaboradores(as) tem em relação à água que o cerca. Uma maneira de perceber os sentidos e significados dados à água por esse ser humano, bem como as distinções expostas entre os(as) diferentes colaboradores(as). Para isso, utilizaram-se as teorias de Bakhtin/Volochinov (1999) e compreendeu-se cada enunciado, seja na fala, na escrita, ou em mapas mentais, levando em conta a necessidade de não apenas saber de antemão a significação das palavras, mas, sim, (re)conhecer e também construir sentidos na cultura na qual esses sentidos adquiriram significações.

No contexto comunicativo é que o sentido se constrói e adquire significações, por isso, na compreensão de enunciados expostos, tanto nas narrativas como nos mapas mentais desses colaboradores amazônicos, a leitura é feita com o conhecimento do contexto comunicativo no qual os sentidos foram produzidos.

Nos diálogos proporcionados pelas narrativas e pelos mapas mentais, esses colaboradores expressaram maneiras de sentir, viver, dizer, observar e estranhar, se misturando na heterogeneidade encontrada nessas comunidades, sentidos que necessitam ser comunicados, ser expressos no espaço. Nessa necessidade do viver ser dialogado com os outros homens, entra em cena a perspectiva do dialogismo bakhtiniano na concretização dessas interlocuções (Sousa, 2012).

Nas narrativas, proporcionadas à pesquisa pela oralidade e pelas imagens (Figura 2), observa-se que os colaboradores estão inseridos na cultura da comunidade pesquisada, construíram sentidos nessa paisagem e, por meio desses sentidos, percebem o perigo. Uma paisagem que eles ajudaram a construir, ali constituíram famílias, educaram os filhos, repassaram sentidos e, com eles, valores. Agora, esses colaboradores sentem receio pela perda do seu lugar.

Com suas experiências pessoais, eles estruturaram e deram o seu tom sentimental às paisagens e, pelos seus sentidos, percebem e vão das experiências aos propósitos enquanto sujeitos. $\mathrm{O}$ conhecimento de mundo que esses humanos amazônicos adquiriram, com todas as suas possibilidades e limitações, permite-lhes fazer o reconhecimento de suas paisagens e, pelas suas narrativas, expõem suas inquietações quanto às modificações por eles observadas.

\section{A análise e os resultados}

A partir da unidade de sentido em Frege ${ }^{9}$ (1978), procurou-se pela compreensão das percepções e representações sociais sobre o elemento água nas comunidades amazônicas como uma estratégia utilizada para desvendar a essência dos atores investigados e assim também desvendar suas lógicas.

\footnotetext{
9 Frege foi um dos fundadores da lógica simbólica moderna, perspectivando a matemática como redutível à lógica. Seus trabalhos fundamentais versam sobre a lógica filosófica, a filosofia da matemática e, sobretudo, sobre a filosofia da linguagem. Conhecido nos estudos da linguagem pela sua teoria do sentido (sinn) e da referência (bedeutung), apresentada na obra Über Sinn und Bedeutung (1892), um estudo que expõe as bases para a distinção descritivista entre sentido e referência, cujos conceitos se tornaram fundamentais para a semântica e a pragmática modernas, tornando-se referência, também, para a filosofia da linguagem.
} 


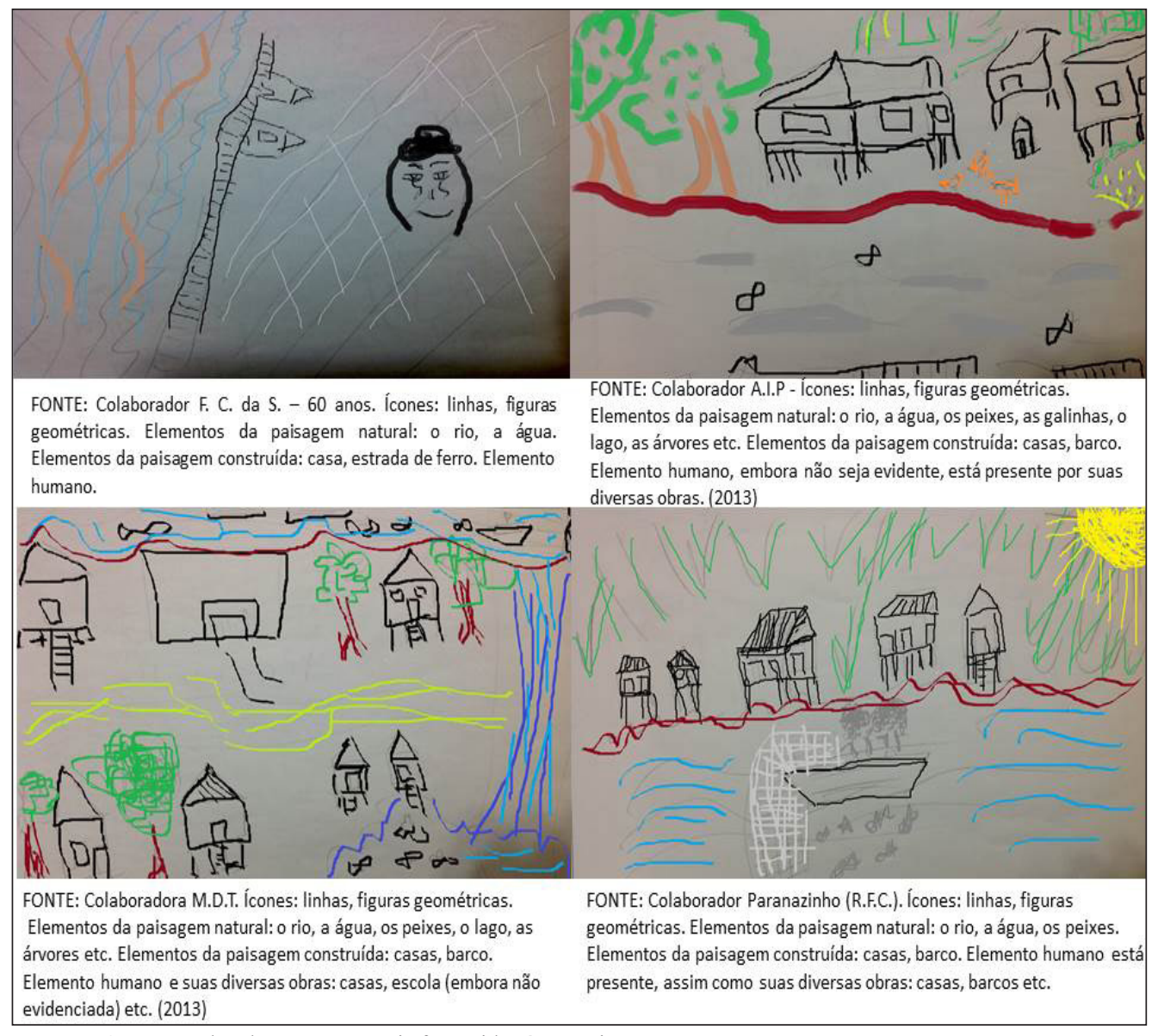

FIGURA 2 - Exemplos de mapas mentais fornecidos à pesquisa.

FONTE: A autora.

Nesse intuito, fez-se uma incursão na teoria sobre o tema e se reconhece que a relação do ser humano com o seu meio é um dos objetos de estudo da Geografia e, na vertente Humana, mais especificamente na Cultural, é que se busca compreender o sentido que o ser humano dá a sua existência.

Com a compreensão de que o sentido é construído culturalmente ${ }^{10}$, a Geografia apoiou-se na fenomenologia e investigou como se dá a percepção humana (funções psicológicas que capacitam o indivíduo a converter os estímulos sensoriais em experiências, organizadas e coerentes) e representações (processos que permitem a evocação de objetos, paisagens e pessoas, independentemente da percepção atual deles) e como se tem utilizado tais conceitos na Geografia.

\footnotetext{
10 O sentido é a ideia compartilhada como referente, isto é, uma concepção geral que permite o entendimento dos significados simbólicos entre os membros de uma mesma cultura (Frege, 1978).
} 
Portanto, a partir da unidade de sentido em Frege (1978), seguiu-se a teoria de Tuan (2012) em seus estudos sobre percepção, atitudes e valores do meio ambiente e a importância do sentido culturalmente construído na percepção individual. Ainda, em busca de compreender o mundo vivido das comunidades analisadas, procurou-se pela fundamentação teórica de Merleau-Ponty (1999) e suas considerações sobre o processo de percepção e apropriação do lugar, levando-se em conta suas digressões sobre as percepções da alma, sentidos e valores espaciais e cromáticos.

Essa reflexão sobre os sentidos e percepções trouxe ao estudo uma aproximação teórica à problematização do objeto em construção. Nesse diálogo com o método fenomenológico da intencionalidade e da intersubjetividade, surgiu a aproximação com Edmund Husserl (1996, 2002) e Alfred Schutz (1979) em busca da essência do fenômeno e do encontro dos sujeitos no seu mundo vivido.

Essa aproximação com o método fenomenológico (intencionalidade e da intersubjetividade) propiciou à pesquisa a concepção do ser observado como sujeito ativo, participativo, evidenciando uma concepção de mundo e relações com o cotidiano, por meio da análise das narrativas, com o auxílio do software ATLAS/ti (Figura 3).

Ademais, os sentidos das comunidades pesquisadas lhes permitem perceber, também, que já há com que se preocupar em relação à água que os cerca. Tais percepções, advindas de sentidos reavaliados pelas constantes mudanças em suas vidas, provocam temores futuros e insegurança nessas comunidades, trazendo consigo as crises de sentido (Berger \& Luckmann, 2012), como mostram alguns entrevistados das comunidades de Porto Velho e de Guajará-Mirim, quando percebem e demonstram essa preocupação em suas narrativas. Suas percepções abarcam desde o futuro das próximas gerações com relação à água até o desaparecimento dos rios perenes com o assoreamento e o desmatamento descontrolados. Essas percepções temerosas foram exibidas em todas as narrativas e se apresentaram da seguinte maneira:

a. preocupação com a água a partir da atitude do governo: governo não demonstra se preocupar com a preservação e/ou limpeza da água;

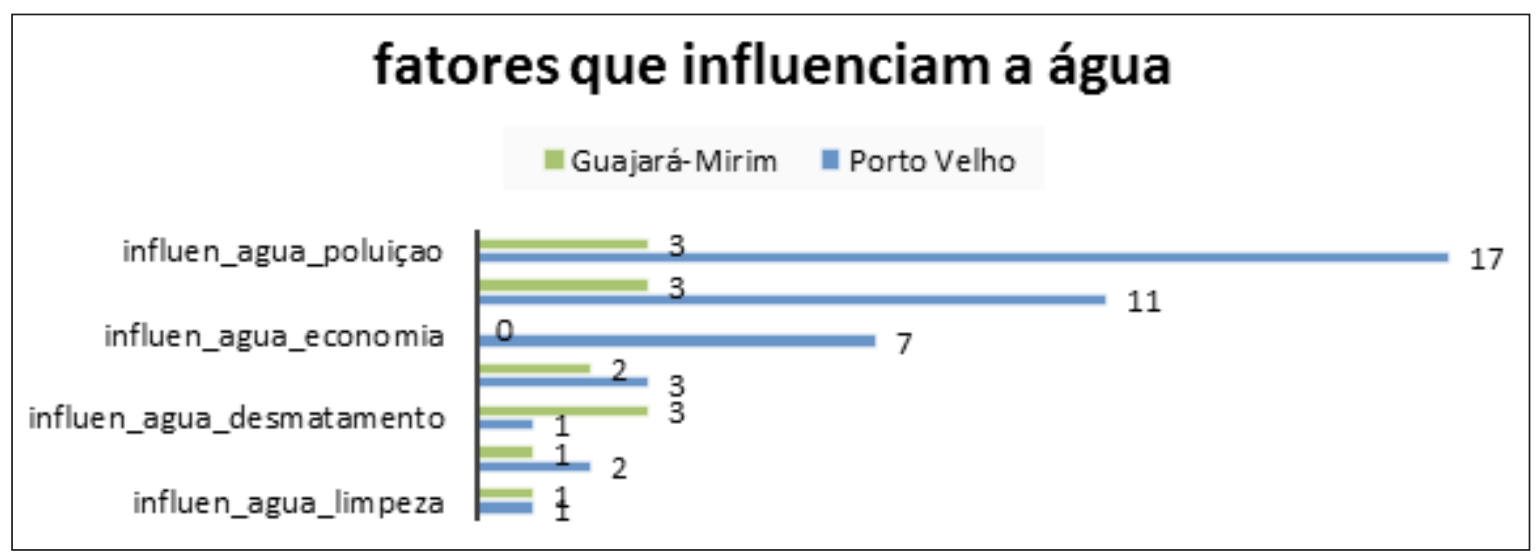

FIGURA 3 - Fatores que influenciam na qualidade da água da Amazônia na visão do sujeito de pesquisa. FONTE: A autora. 
b. preocupação com a água a partir da poluição: poluição como uma preocupação dos moradores em relação à água (água poluída);

c. preocupação com a água para gerações futuras: preocupação com a água por conta das gerações futuras;

d. preocupação com a água devido ao descarte do lixo: preocupação com o lixo que polui a água;

e. preocupação com a água com o desaparecimento de rios: preocupação com o assoreamento do rio.

Entrevistados de Porto Velho e de Guajará-Mirim mostram que percebem a modificação de suas águas e demonstram, em suas narrativas, preocupações com o futuro das próximas gerações. Os colaboradores de Guajará-Mirim se preocupam com a poluição, com o assoreamento e com a possibilidade do desaparecimento dos rios. Mesmo com a preocupação voltada, também, para a geração futura, a comunidade guajaramirense não responsabiliza o governo ou sua ineficiência quanto à ausência de fiscalização ou quaisquer outras responsabilidades sobre essas preocupações. As percepções observadas nas comunidades porto-velhenses e na comuni- dade guajaramirense se apresentaram nas narrativas da seguinte forma (Figura 4):

Quanto aos colaboradores de Porto Velho, devido à grande imigração provocada pelas construções das duas hidrelétricas dentro do seu espaço, Santo Antônio e Jirau, com todo o contingente de pessoas e empresas atraídas por esses empreendimentos, mostram em suas percepções que seus hábitos evidentes foram ameaçados e lhes trouxeram não somente a construção de novos sentidos, mas também a crise de sentidos proporcionada pelas mudanças radicais nas vidas de suas comunidades. Desse modo, suas percepções indicaram desde a preocupação com o lixo, com o assoreamento dos rios, com a poluição dessas águas, mas também apontam para a falta de responsabilidade ambiental do governo.

Para estudar as representações sociais nas comunidades amazônicas, partiu-se do princípio de que o pensamento dos moradores a respeito da água não deixa de ser, como as representações sociais, uma realidade mental. Ao mesmo tempo, a água é uma realidade concreta, material e socialmente localizada. De acordo com Peluso (1998), é nessa encruzilhada em que um objeto tanto é uma realidade mental como uma realidade social e espacial que

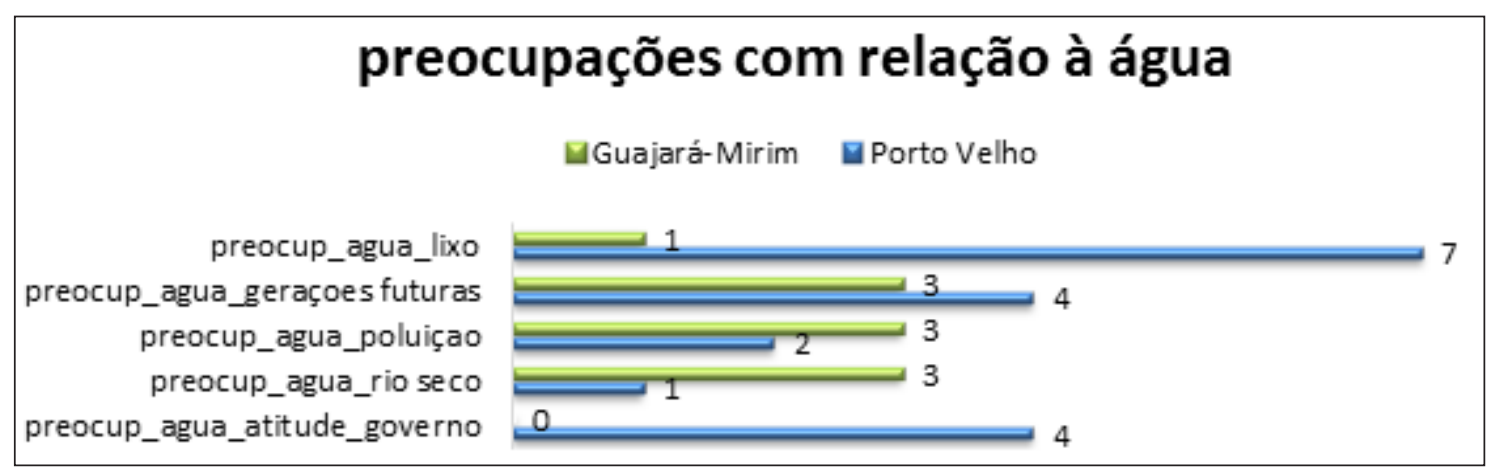

FIGURA 4 - Preocupações dos sujeitos de pesquisa com o futuro da água. FONTE: A autora. 
se forma o ambiente propício para que os moradores elaborem suas representações sociais.

Para desvendar as representações sociais dos colaboradores de pesquisa, procurou-se captar o olhar do morador sobre sua água, entrando nos códigos de possessão do objeto, das facilidades, das dificuldades, da vivência. Uma análise para conhecer os sentidos que constituem o seu pensar, esse mesmo sentido que constitui os seus códigos simbólicos formados a partir de sua cultura e comunicados aos outros pela sua linguagem, fazendo de sua representação subjetiva a representação do outro, tornando-a social. A influência de uma pessoa sobre outra acontece principalmente pela comunicação de um pensamento. De acordo com Frege (1978), alguém comunica um pensamento e causa mudanças no mundo externo normal ao induzir essa outra pessoa a aprender o seu pensamento e aceitá-lo como verdadeiro (Moscovici, 2011).

Os códigos das representações sociais são importantes, pois dele deriva a relação dos sujeitos entre si e com a água que os cerca, mostram os modos de pensar sobre a água e os processos que a atravessam, reconhecem a si mesmos e aos outros sujeitos segundo as várias categorias do viver essa água.

A lógica de comunidade, neste estudo, é compreendida como a identidade manifestada pelos colaboradores de uma mesma comunidade, observada como uma forma de vínculo com outros membros locais, pelo comprometimento com esse grupo, manifestado pela defesa de valores e ideologias enraizadas na cultura local (Thornton et al., 2012).

Sobre esses laços e a noção de uma vida significativa, Widenfeld, no prefácio da obra Modernidade, pluralismo e crise de sentido: a orientação do homem moderno, afirma que tais laços e noções "só são partilhados por pequenas comunidades" e por isso "é importante observar como os indivíduos se unem nesta comunidade" (Berger \& Luckmann, 2012, p. 9).

Álvaro Heidrich (2013, p. 53) corrobora essa ideia ao declarar que "uma vida plena de sentido é naturalmente reconhecível em comunidades pequenas e tradicionais", e lembra ainda que, na complexidade do cotidiano moderno, "o sentido é reelaborado por instituições e meios produtores de ideias e mensagens".

Ademais, nas comunidades, vê-se, também, que as compreensões se renovam e, por meio da exposição da ideia por outro sujeito ou grupo, aquilo que não faz parte da compreensão de um pode se tornar presente e compreensível. "Para a composição do vivido o diálogo é imprescindível. O que se põe em relação na vida social, ao mesmo tempo em que afeta também é afetado" (Heidrich, 2013, p. 53).

Nas comunidades amazônicas investigadas, compreendidas, aqui, como comunidades geograficamente localizadas, perceberam-se suas lógicas como o produto da soma de seus sentidos, suas percepções e suas representações sociais, cuja origem está atrelada ao processo formado e formador da vida dessas comunidades e que se veicula pela comunicação.

No trabalho de campo, com a coleta e a análise dos dados, foi possível observar os valores e ideologias dessas comunidades amazônicas, portanto, foi possível também observar suas lógicas. Uma lógica de comunidade compreendida durante todo o caminhar da pesquisa como a identidade manifestada pelos colaboradores de uma mesma comunidade, observada como uma forma de vínculo com outros membros locais, pelo comprometimento com esse grupo, manifestado pela defesa de valores e ideologias enraizadas na cultura observada.

Nas narrativas, observou-se como esses membros organizam as regras do grupo, suas maneiras 
de agir, seus modos e costumes com sentidos e valores (re)criados dentro do espaço onde eles atribuem novos significados e que possuem uma carga simbólica situada no interior de cada grupo. Regras, valores e pontos de vista que são repassados por diferentes modos de comunicação, constituindo-se estratégias de sobrevivência coletiva. Enquanto as comunidades de Porto Velho vivem essa lógica do temor como uma lógica da realidade vivida, a comunidade de Guajará-Mirim, em vários aspectos, vive a lógica do imaginário, como se mostra na Tabela 4, pela análise de suas narrativas:

TABELA 4 - Semelhanças e diferenças entre as Lógicas de Comunidade observadas nas comunidades de Guajará-Mirim e Porto Velho.

\begin{tabular}{|c|c|c|}
\hline & Guajará-Mirim (6)* & Porto Velho (25)* \\
\hline $\begin{array}{l}\text { Lógicas do } \\
\text { temor } \\
\text { (Lógicas reais) }\end{array}$ & Inundação (2) & $\begin{array}{l}\text { Perda da pesca (20) } \\
\text { Migração } \\
\text { compulsória à } \\
\text { cidade (4) } \\
\text { Poluição (21) } \\
\text { Inundação (3) }\end{array}$ \\
\hline $\begin{array}{l}\text { Lógicas da } \\
\text { preocupação } \\
\text { (Lógicas do } \\
\text { imaginário) }\end{array}$ & $\begin{array}{l}\text { Perca da pesca (2) } \\
\text { Migração compulsória } \\
\text { à cidade (2) } \\
\text { Desastres ambientais } \\
\text { causados por possíveis } \\
\text { acidentes nas } \\
\text { hidrelétricas (3) }\end{array}$ & $\begin{array}{l}\text { Desastres } \\
\text { ambientais } \\
\text { causados por } \\
\text { possíveis acidentes } \\
\text { nas hidrelétricas } \\
(17)\end{array}$ \\
\hline
\end{tabular}

*Número de narrativas que expõem esses sentidos. FONTE: A autora.

Diferente de outras narrativas expostas em outros estudos amazônicos (Silva, 2007; Sousa, 2012), nessas narrativas a poética ficou ausente. Embora, esses colaboradores tenham na água o lugar de vida, com o respeito e o cuidado que surgem a partir dos sentidos criados e recriados nesse contexto maior de espacialidades dentro de um viés cultural e social, observou-se que as relações que os indivíduos estabelecem com a água que dá sentido às suas vidas estão afetadas pela crise de sentidos.
Essa crise de sentidos encontrou as condições gerais para o seu surgimento a partir do momento em que os sentidos construídos na cultura de cada comunidade ribeirinha analisada, os mesmos sentidos conservados e repassados de geração a geração (sentidos subjetivos), começam a não coincidir com os sentidos da sociedade em que ele está inserido (sentidos objetivos).

Desse modo, o homem/mulher colaborador desta pesquisa, que vivia em perfeita concordância com sua comunidade de vida e sua comunidade de sentido, ou seja, tinha sentidos concordes no modo de viver a água, sentir e perceber, começa a estranhar sua água e já não encontra nas águas do rio os sinais sobre as condições do tempo, sobre os próximos dias de sol ou de chuva, sobre a oportunidade de boa pesca e, desse modo, começa, também, a estranhar seus próprios sentidos, crenças e valores, instalando-se a crise de sentidos.

A partir dessa crise de sentidos que os conduz a um sentimento de desestruturação de suas vidas e de suas próprias identidades, originam-se outros comportamentos que conduzem a uma lógica de comunidade de tensão. Desse modo, para o entendimento dessa lógica, foi necessário também fazer uma imersão nas relações dos indivíduos para a compreensão do seu universo cultural.

A convivência do homem com o rio, principalmente nas comunidades porto-velhenses, provoca o estado de tensão em diversas situações. Tensão que tem várias causas, desde as construções de duas grandes hidrelétricas em suas águas (no Rio Madeira), com todas as mudanças que isso representa, transpassando pelas inúmeras informações desencontradas de possíveis desastres naturais (por meio das diversas mídias), até a imensa e constante recepção de imigrantes que, por possuírem sentidos construídos em culturas diversas, veem a cultura 
local, seus sentidos e valores com preconceitos colonizadores.

Desse modo, nas narrativas, encontraram-se a pluralidade de vozes históricas que interpretam as águas dessa parte da Amazônia, desenham o modo de vida das comunidades e trazem à tona seus temores que evidenciam a paisagem encontrada, revelando traços importantes na ocupação do espaço. Um espaço mediado pela linguagem, pela crise de sentidos, pelas múltiplas interferências que compõem o imaginário e a história dessas comunidades amazônicas.

Essas narrativas expressam, portanto, não só as maneiras de sentir, viver, dizer, observar e estranhar o espaço ribeirinho amazônico, mas também a lógica das comunidades pesquisadas. Uma lógica composta de sentidos, percepções e representações sociais que, por enunciados heterogênicos, se mostra na tensão e pede por atenção à água e soluções, exibindo os fenômenos sociais e as problemáticas que cercam as águas dessa parte da Amazônia (Quadro 1).

Com lógicas formadas a partir da relação dialética entre o espaço vivido e o espaço concebido, com consciência socioespacial de pertencimento e identidades territoriais, essas comunidades, que mantinham estreita relação humanizada com os componentes dos rios e das matas, encontram-se, agora, com o desconhecido, com a procura do lugar, sem a sutileza do encantamento ou maravilhamento antes encontrado na água que os cerca.

Essas lógicas encontradas manifestam a identidade dos colaboradores dessas comunidades e formam vínculos entre os membros locais, for-

QUADRO 1 - As lógicas compostas por sentidos, percepções e representações sociais presentes nas enunciações.

"Vi muita modificação aqui depois que começaram as Usinas. Porque os peixes não estão bons. Tem vez que a gente pega o peixe baixando o rio, o bichinho ainda está vivo, mas já está podre". (PD31: T. B. - Comunidade Niterói Porto Velho).

"Eu vivia da pesca e hoje ninguém pode pescar mais porque o rio cavou" (PD18: J. R. R. F. - Comunidade São Sebastião Porto Velho).

"A gente sofre muito porque aqui não tem como ganhar dinheiro, aqui o que tinha era a pesca e eles cortaram tudo da gente. Tudo. E a gente vai viver do quê? Nossa vida depois desses empreendimentos tem uma grande diferença” (PD2 M. de J. Comunidade Agrovila Porto Velho).

"Essa água do rio Madeira, depois dessa usina aí, ficou muito esquisita. Antigamente não, mas agora é difícil eu beber a água do rio. Ela ficou muito feia, muito... Sei lá, ficou esquisita, a cor da água” (PD9: E. P. - Comunidade Niterói Porto Velho).

"Depois das Usinas teve muita modificação. Antigamente levantava muito peixe, agora você passa a semana todinha aí para matar um peixe, dois. Há muito pouco. Só da pescaria a gente não sobrevive mais, tem que fazer outra coisa, plantar, criar e pescar para sobreviver". (PD11: F. C. B.- Comunidade Niterói Porto Velho).

“Antigamente, até 2011, a gente podia utilizar essa água, a água do Rio Madeira era a água de casa, mas depois da Usina a água ficou contaminada...” (PD12: F. C. - Bairro Triângulo Porto Velho).

"Quanto a esses empreendimentos, a construção dessas Usinas, teve uma reunião aí, mas, é aquele negócio, Uns achavam que era bom, outros achavam que não era. No final foi construída e quando terminar vai todo mundo embora e a gente, que é pescador, fica aí lascado, vai ter que mudar de profissão" (PD13: F. V. de M. - Comunidade Niterói Porto Velho).

FONTE: A autora. 
talecendo o comprometimento do grupo. Esse fortalecimento foi observado nas constantes reuniões em busca da defesa de valores e ideologias enraizadas na cultura local. Essa lógica de comunidade é responsável pela valorização dos laços fortes e duradouros entre os membros dessas comunidades.

Observou-se que, embora os sentidos, as ideias e os pontos de vista (percepções e representações) se renovem, se modifiquem e sejam repassados e reconstruídos pela comunicação, as comunidades analisadas passam pela crise de sentidos e formam lógicas, a partir daí, repletas de temores e preocupações, com bases em fatos e fenômenos antes ausentes em seus mundos vividos. Tais lógicas conduzem a ligações emocionais novas e estranhas ao grupo, desestabilizando-as e quebrando paradigmas antes existentes.

\section{Conclus̃̃es}

Neste estudo, sob as categorias da geografia e sob o olhar do geógrafo que não nega o papel das forças sociais, políticas e econômicas na (re) construção das paisagens, por meio de dados fundamentados, confirmou-se que a valorização dos elementos naturais sofre interferência dos sentidos culturalmente construídos pelo homem/mulher amazônico e, por isso mesmo, esses sentidos thes permitem perceber e representar de modos diferenciados os elementos naturais que os cercam.

Pelos dados analisados, verificou-se que, embora a água tenha um papel privilegiado na vida desses colaboradores, a margem do rio, o viver entre o rio e a floresta, nessas comunidades investigadas, hoje, já não lhes permitem ver os enigmas da Amazônia.

Esse viver ribeirinho, embora ainda ofereça interrogações sobre origens e destinos a esse ho- $\mathrm{mem} /$ mulher e a água transcenda sua materialidade e lhes imponha toda uma série de concepções sobre o viver à beira do rio, as narrativas que remeteram a uma realidade psíquica construída sobre vivências geradas a partir dessas águas apresentaram, também, as grandes mudanças ocorridas nesse viver que transforma objetiva e subjetivamente esse ser humano e exibiram o seu mundo vivido como um universo reificado.

Uma realidade que mostrou que, embora os devaneios e a construção do Eu derivem da água que os cerca, o objeto água adquiriu a condição do Outro. Um espaço percebido por esses homens/ mulheres por meio de sua situação nesse mundo vivido que os fazem reafirmar suas opções em viver à beira do rio, mas que lhes permite, também, a percepção de problemas graves em suas águas e a preocupação com as gerações futuras.

Nas comunidades porto-velhenses, essa realidade atinge a própria objetivação de ser um ribeirinho e conduz a ver essa mesma água que, para eles, anteriormente estabelecia a sua identidade e lhes permitia construir um diálogo entre o sujeito e o mundo em um território valorizado emocionalmente, mas, hoje, cria relações de diversidade e tensão entre esses dois espaços, articulados e contraditórios: os pequenos espaços individualmente significativos e os macroespaços socialmente construídos.

Nessas comunidades porto-velhenses, ficou claro que suas representações sociais em relação à água já não se ancoram em condições de vida anteriores (fartura da pesca, enchentes com épocas certas, espaço de criação e plantio), ancoram-se em condições adversas (construção de usinas, falta do peixe, desbarrancamento e enchentes constantes).

Desse modo, o ser ribeirinho, que antes thes permitia desaguar no imaginário com um espontâneo maravilhamento diante dos acasos, dos mitos e 
das lendas, não mais os privilegia com a contemplação que os conduzia a olhar as coisas com devaneio e gratuito prazer da imaginação.

As margens do Rio Madeira, que antes pareciam não exigir lógica para ser coerentes, hoje, apresentam as comunidades em crise de sentidos, cujas comunidades de sentidos e comunidades de vida já não concordam entre si, o que torna mais difícil a manutenção da concordância nos processos que formam a identidade pessoal e também promovem o surgimento de lógicas de tensão e de preocupação com suas próprias vidas e com a sua água, formando um grupo social composto pelas diferentes comunidades e conduzindo a um fortalecimento de objetivos em comum.

A comunidade guajaramirense mostrou à pesquisa que constrói e/ou reavalia seus sentidos a partir da mídia e do censo comum e, embora ainda apresente alguma serenidade no viver próximo às águas, também já demonstra lógicas de preocupação com a sua água e a sua vida. Essa preocupação deriva da observação do assoreamento dos seus rios, resultado do intenso desmatamento, até o temor da construção de novas hidrelétricas em suas águas.

A serenidade que advinha das águas, ainda presente na comunidade guajaramirense, deu lugar à inquietação nas comunidades porto-velhenses. As experiências do cotidiano, da leitura das águas na previsão de tempestades, da estiagem, do bom tempo ao plantio ou à praia do turismo, hoje, se mostram no estranhamento ao Rio Madeira.

A admiração e o maravilhamento que nasciam da própria contemplação da água, das particularidades de onde brotavam as sensações e permitiam ao espírito ribeirinho sonhar e ver em fenômenos naturais as explicações metafóricas, numa poética iluminada pela religiosidade dos mitos, formas de explicação por meio do irrepresentável da representação, em suas narrativas se mostraram ausentes.
No entanto, nesse espaço no qual a água amazônica não é apenas um recurso natural, ou uma paisagem portadora de belezas naturais, encantamentos, mitos e crenças, a água ainda se mostra mais. Ela representa a vida dessas comunidades. Uma vida composta de importantes peças que compõem o mosaico das paisagens culturais investigadas.

Reconheceu-se, portanto, a importância de estudos geográficos para intervenções urgentes nas gestões, outorgas e/ou empreendimentos nas águas em rios Amazônicos. Uma bacia hidrográfica importantíssima e que tem sido utilizada sem respeito aos sentidos e significados do ser humano local. Uma utilização irresponsável com outorgas de direitos fornecidos pela Agência Nacional de Águas (ANA) de maneira ilegal, visto que em nenhum rio amazônico foram instalados os comitês de bacia que, de acordo com a Lei das Águas (9.433/97), deveriam ser responsáveis por planejar o uso das águas.

Com este estudo, por meio da Geografia Cultural, abrem-se perspectivas antes ignoradas e desvendam-se sentidos nas diversidades que podem e devem indicar caminhos a projetos em águas amazônicas que levem em conta os sentidos culturalmente construídos nessas comunidades geograficamente localizadas, evitando, desse modo, crises ambientais com práticas gerenciais inadequadas.

Em uma época em que o problema com a escassez da água é sentido em várias regiões do Brasil e no mundo, com a contaminação e o assoreamento de rios, é de extrema importância (re)pensar na preservação da água na Amazônia. Por isso, estudos geográficos, a partir do sentido, das percepções e das representações sociais do homem/mulher amazônico se impõem. Isso porque são essas lógicas, a partir de comunidades geograficamente localizadas, que poderão auxiliar e fornecer as ferramentas cognitivas necessárias para as políticas de gestão que conduzam a outorgas e/ou empreendimentos com maior responsabilidade. 


\section{Referências}

Adams, H.; Searle, L. Critical Theory. Flórida: University of Florida, 1985.

Agra, K. L. de O. Águas da Amazônia: sentidos, percepções e representações. Curitiba, Tese (Doutorado em Geografia) Universidade Federal do Paraná, Setor de Ciências da Terra, Programa de Pós-Graduação em Geografia. Orientadora: Salete Kozel, 2015.

Aragón. L. E. Novos temas regionais para o estudo da Amazônia no atual contexto internacional. Trabalho apresentado na mesa-redonda "O tempo curto e o tempo longo: questões emergentes e questões ausentes da pesquisa em estudos urbanos e regionais". 58 Reunião da SBPC, Florianópolis, 17-21 julho, 2006.

Bakhtin, M./Volochinov. Marxismo e filosofia da linguagem. São Paulo: Hucitec, 1999.

Berger, P.; Luckmann, T. Modernidade, pluralismo e crise de sentidos: a orientação do homem moderno. Trad. de Edgar Orth. Petrópolis, RJ: Vozes, 2012.

Claval, P. Terra dos homens: a geografia. Trad. de Domitilia Madureira. São Paulo: Contexto, 2010.

Claval, P. Do olhar do geógrafo a Geografia como estudo do olhar dos outros. Conferência Proferida no IV Simpósio Nacional Espaço e Cultura. Rio de Janeiro: UERJ. Outubro de 2004.

Cosgrove, D. Geografia cultural do milênio. In: Rosendahl, Z. C.; Roberto L. (Org.). Manifestação da cultura no espaço. Rio de Janeiro: EDUERJ, 1999. p. 17-46.

Dardel, E. O homem e a terra: natureza da realidade geográfica. Trad. de Holzer Werther. São Paulo: Perspectiva, 2011.

Dias, M. A. R.; Aragón, L. E. Cooperação amazônica para o conhecimento e o uso sustentável dos recursos hídricos da região. In: Aragón, L.; Clüsener-Godt, M. (Orgs.). Problemática do uso local e global da Amazônia. Bogotá, Colômbia: D.E.FEN, 1987. p. 33-54.

Fernandes, D.; Gil Filho, S. F. Geografia em Cassirer: perspectivas para Geografia da Religião. GeoTextos (Salvador), 7, 211-228, 2011.

Frege, G. Lógica e filosofia da linguagem. São Paulo: Cultrix, 1978.
Heidrich, Á. L. et al. (Orgs.). Maneiras de ler: geografia e cultura [recurso eletrônico]. Porto Alegre: Imprensa Livre/ Compasso Lugar Cultura, 2013.

Husserl, E. Investigações lógicas - sexta investigação: elementos de uma elucidação fenomenológica do conhecimento. São Paulo: Nova Cultural, 1996. (Coleção Os Pensadores)

Husserl, E. A crise da humanidade europeia e a filosofia. 2. ed. Porto Alegre: EDIPUCRS, 2002. (Coleção Filosofia, 41)

Kozel, S. Mapas mentais - uma forma de linguagem: perspectivas metodológicas. In: Kozel S. et al. (Org.). Da percepção e cognição à representação: reconstruções teóricas da Geografia Cultural e Humanista. São Paulo: Terceira Margem, 2007. p. 114-138.

Meihy, J. C. S. B. Manual de História Oral. São Paulo: Loyola, 2005.

Merleau-Ponty. Fenomenologia da percepção. Trad. de C. A. R. Moura. São Paulo: Martins Fontes, 1999.

Moscovici, S. Representações sociais: investigações em Psicologia Social. Trad. de Pedrinho A. Guareschi. Petrópolis: Vozes, 2011.

Peluso, M. L. O morar na constituição subjetiva do espaço urbano: as representações sociais da moradia na cidade-satélite de Samambaia/DF. São Paulo, Tese (Doutorado) - Pontifícia Universidade Católica de São Paulo, São Paulo, 1998.

Plano Nacional de Recursos Hídricos. 2010. Disponível em: <http://www.brasil.gov.br/meio-ambiente/2009/10/ rios-e-bacias $>$. Acesso em: 25 jul. 2003.

Schutz, A. Fenomenologia e relações sociais. Rio de Janeiro: Zahar, 1979.

Silva, J. da C. O mito e as crenças como constituintes do espaço ribeirinho na formação do modo de vida amazônico. In: Kozel, S. et al. (Orgs.). Da percepção e cognição à representação: reconstruções teóricas da Geografia Cultural e Humanista. São Paulo: Terceira Margem; Curitiba: NEER, 2007. p. 231-240.

Sousa, L F. Espaços dialógicos dos barqueiros na Amazônia: uma relação humanista com o rio. Curitiba, Tese 
(Doutorado) - Programa de Pós-Graduação em Geografia, Setor de Ciências da Terra, Universidade Federal do Paraná - UFPR, 2012.

Strauss, A.; Corbin, J. Basics of qualitative research: techniques and procedures for developing Grounded Theory. 2. ed. Thousand Oaks: Sage Publications, 1998.

Strauss, A.; Corbin, J. Pesquisa qualitativa: técnicas e procedimentos para o desenvolvimento de teoria fundamentada. Porto Alegre: Artmed, 2008.
Thornton, P. H.; Ocasio, W.; Lounsbury, M. The institutional logics perspective. Oxford: Oxford University Press, 2012. (in press).

Tuan, Y-F. Topofilia: um estudo de percepção, atitudes e valores do meio ambiente Trad. de Lívia de Oliveira. São Paulo: DIFEL, 2012. 